\title{
Turnover rates are decreasing in California dairies
}

by Gregorio Billikopf and Gustavo González

Dairy employees in the San Joaquin Valley are staying longer in their jobs. Our study in 2009 showed that the average length of employment has increased $250 \%$ since 1953 and $40 \%$ since 1984. However, tenures among non-Hispanic employees were twice as long as among Hispanic employees, suggesting there are opportunities to further increase workforce stability. The reasons why workers leave dairies are mostly the same as they were 30 and 60 years ago. We also compared our 2009 California interview results with recent studies in the eastern United States, where trends were similar.

D airy is California's top agricultural commodity, valued at $\$ 5.9$ billion in 2010 (CDFA 2012). The dairy industry employs 443,574 full-time workers (California Milk Advisory Board 2011), of whom 17,000 (fewer than $4 \%$ ) work in dairies (Ellerby 2010). Labor represents $10.3 \%$ of dairy production costs; since 2006 it has ranged from $9.5 \%$ to $12.1 \%$ (CDFA 2011). Merced, San Joaquin and Stanislaus counties are among the top 10 dairy counties in the United States; other top dairy counties in California include Fresno, Kings, Riverside, San Bernardino and Tulare.

Dairies are labor intensive because cows are milked two or three times per day year-round. Excessive employee turnover is expensive and upsets routines, which in turn can affect animal health and dairy productivity. By all accounts, 2009 was the worst year since the Great Depression (Willis 2009) for U.S. industries, including dairies (Barrett 2012). As a recession intensifies, the number of employees who voluntarily quit generally goes down while the number of terminations increases. Using Bureau of Labor Statistics data, Hill (2011) showed exactly that pattern between 2007 and 2010, with 2009 as the peak year for terminations and the lowest year for voluntary quits.

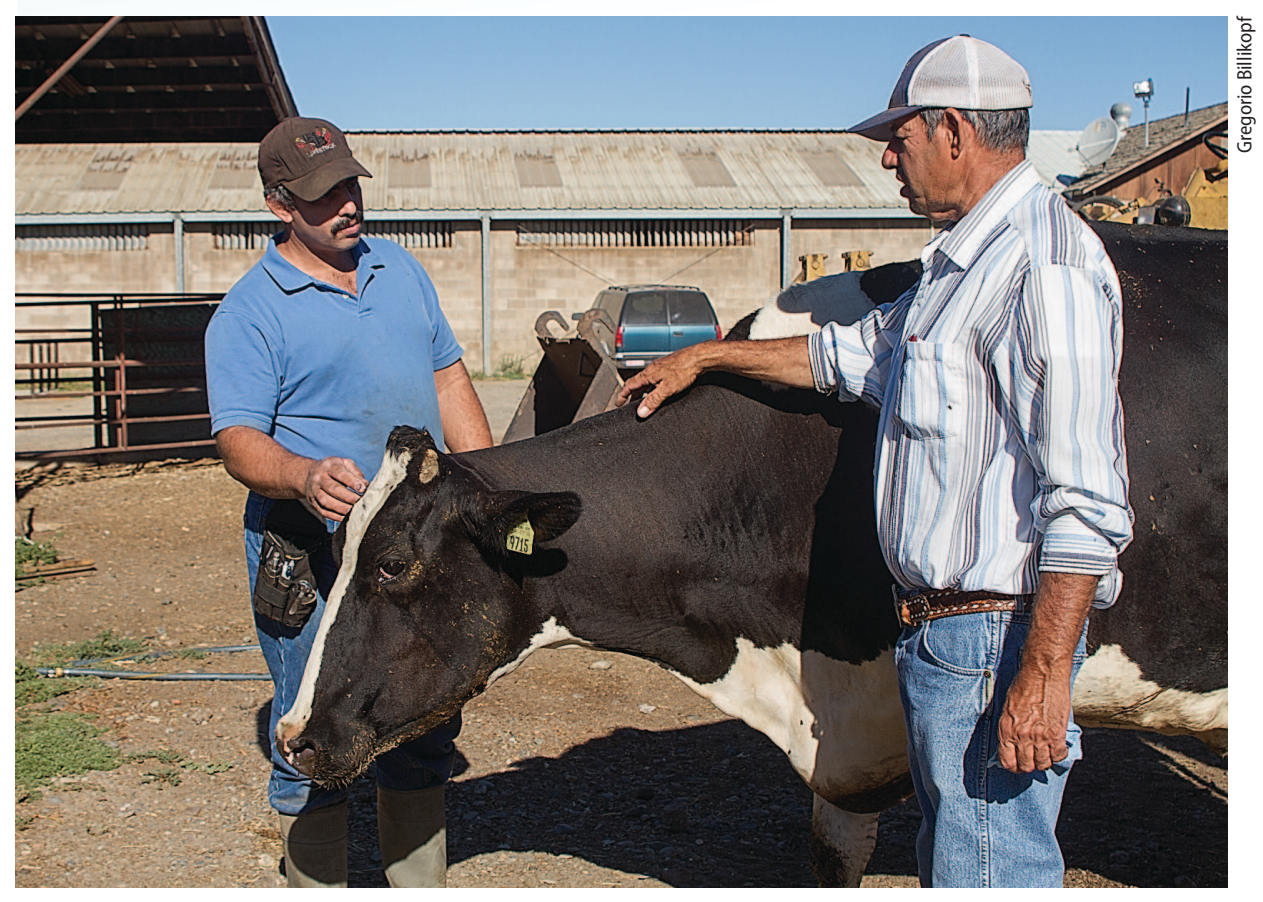

Dairy production cannot be readily downsized in response to labor shortages, making employee turnover an ongoing management concern.

In agriculture, the willingness to terminate may have been offset during this time by employers' concerns about labor shortages; many employees are undocumented, and there is great uncertainty regarding immigration reform. According to the National Milk Producers Federation, $20.5 \%$ of dairy farmers faced a labor shortage in the months leading up to a 2009 survey and $18.7 \%$ feared a shortage (Jordan 2009).

\section{Costs of turnover}

In most industries, the costs associated with employee turnover are significant; they include losses in productivity (pre-turnover as well as post-turnover); recruitment, selection and hiring; safety issues; and the orientation and training of new employees (Bliss 2010, 2012; CEPR 2012; O'Connell and Kung 2007). Labor experts often speak of turnover costing about $150 \%$ of an employee's annual wages (Bliss 2012; O'Connell and Kung 2007) and as much as $250 \%$ (Bliss 2012) for employees with managerial responsibilities. Bureau of Labor Statistics data (O'Connell and Kung 2007; Smith 2006) shows turnover costs in manufacturing and construction (the industries closest to agriculture) are close to $75 \%$ of the highest turnover costs in any industry (found in information management) and double the lowest turnover costs of any industry (leisure and hospitality).

The high turnover costs in dairies are partly due to the nature of dairy management. Dairy production cannot be downsized temporarily in response to labor shortages as easily as in retail or manufacturing. When a worker quits, a substitute must be found to do the work until the worker is replaced. Labor-management challenges (e.g., poorly designed pay for performance systems, ineffective supervision, interpersonal conflicts among dairy employees) may cause unwanted turnover (Billikopf 2003a). Dealing with these underlying difficulties can help dairy managers reduce turnover and improve worker morale and productivity.

For some workers, job dissatisfaction has to be quite high before they will seek other employment, because changing jobs can also be traumatic

Online: http://californiaagriculture.ucanr.edu/ landingpage.cfm?article=ca.v066n04p153\&fulltext=yes DOI: 10.3733/ca.v066n04p153 
(Jex and Gudanowski 1992). The period before a worker's separation may be accompanied by reduced productivity and increased absenteeism. This absenteeism is sometimes physical (the worker doesn't show up) and at other times mental (the worker is present, but his or her mind is somewhere else, which is sometimes described as "quit and stayed") (Billikopf 2003a).

\section{Turnover classifications}

There are a number of ways to classify worker turnover (Billikopf 1984, 2003a; Milkovich and Boudreau 1994). Some turnover may be beneficial. A dairy manager may look at the voluntary departure of an employee as an opportunity to hire a better-qualified individual without having to fire one. It may also be an opportunity to replace a long-term employee who is earning a high wage with a lower-paid, entry-level person (Billikopf 2003a).

Turnover can be classified by the degree of control the dairy manager has over the separation. For example, managers have more control over pay issues than over employees' personal problems, milk prices and other economic conditions that affect the dairy's well-being. Separations can also be classified as either producer initiated (firings and layoffs) or worker initiated (quits). Regardless of how turnover is classified, dairy managers can benefit from a better understanding of why workers leave dairies.

\section{Measuring length of employment}

There are three ways to measure the length of employment (LOE), or tenure, of employees.

Snapshot. This approach records the worker's exact length of employment in his or her current job at the time of a survey or interview (Stack et al. 2006). For example, an employee who has been on the job for 3 days at the time of a survey is reported as having a 3-day length of employment. This approach does not take their present job throughout their careers, is not included.

Range. This approach measures the percentage of workers who fall into specific length-of-employment ranges; for example, $4 \%$ may have worked less than 2 years, $15 \%$ between 2 and 6 years, and so on (Maloney and Grusenmeyer 2005; Marchand et al. 2008). The ranges are seldom the same, however, so these studies are less useful for comparative research.

\section{Survey of dairy workers}

In our 2009 study, we compared the snapshot and completed-tenure approaches. We looked at length of employ-

\section{Over the years, compensation and benefits are the top reasons employees have given for leaving their jobs.}

into account whether that individual will work 1 more week or 3 more decades, but if a large number of subjects are surveyed, the length-of-employment measures should even out.

Completed tenure. This approach measures the worker's total time on a dairy job after he or she has left it (Billikopf 1984). The greatest concern with this method is that data for employees who are new to the industry, or who have held

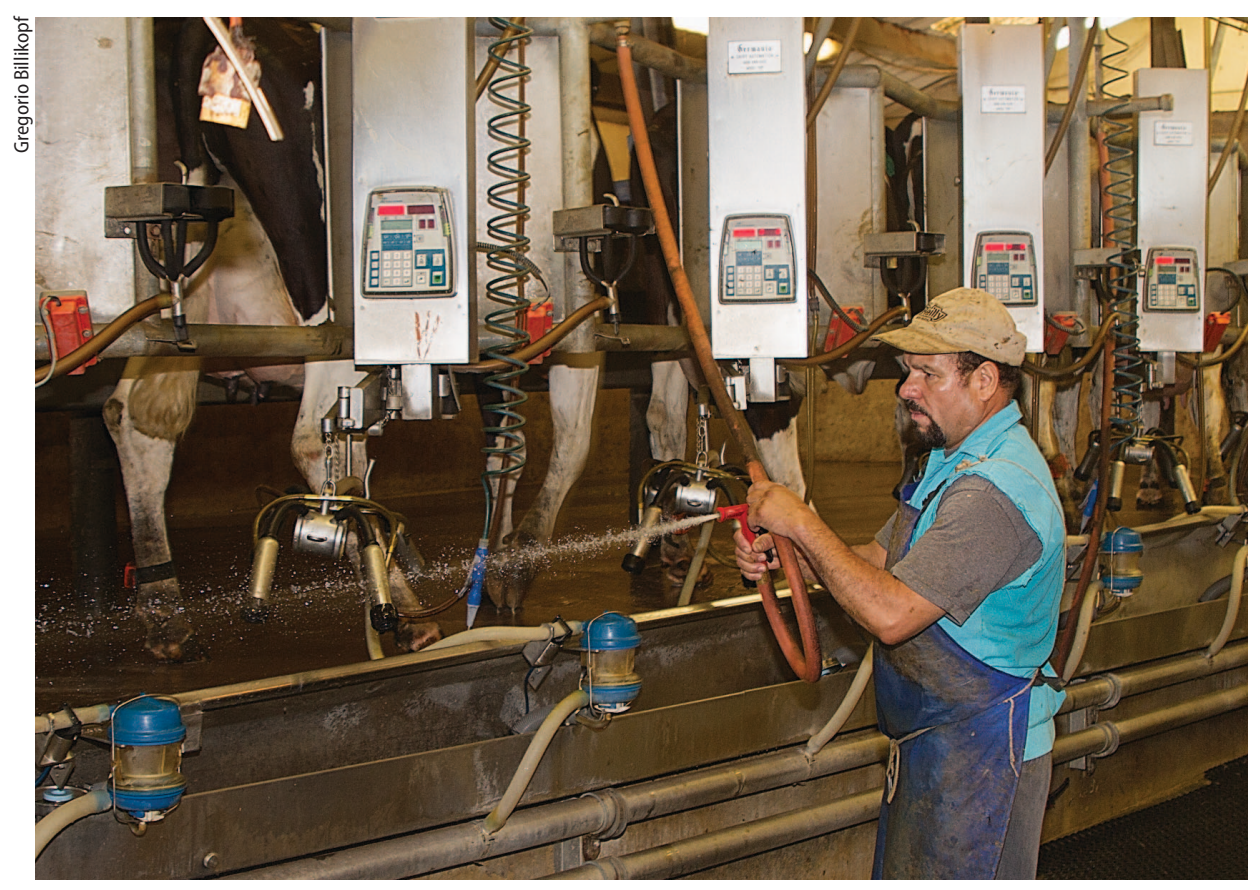

In a recent survey of San Joaquin Valley dairy workers, the reasons most often cited for leaving employment were compensation and benefits, economic problems at the dairy, and personal and family matters. ment and the reasons why dairy workers leave jobs. We compared the data with that from two previous dairy turnover studies - one by Fuller and Viles (1953) in Fresno County and the other by Billikopf (1984) in San Joaquin, Stanislaus and Merced counties. We also compared the data with studies conducted outside of California.

The second author conducted most of the interviews and drove to locations in San Joaquin, Stanislaus and Merced counties where there is a high density of dairy operations. He stopped at dairies and asked permission to interview employees. No attempt was made to collect data from workers who had left the industry permanently (e.g., for a job in another industry or because of disability, unemployment or retirement). Our survey followed the approach used by Billikopf (1984).

Demographics. In our sample, all respondents were male $(n=209)$. By job category, $50 \%(n=103)$ were milkers, $19 \%(n=40)$ were cow feeders, $17 \%(n=$ $35)$ were calf feeders, $12 \%(n=25)$ were herdspeople, $1 \%(n=2)$ were relief workers or helpers and $0.5 \%(n=1)$ were maternity workers (responsible for taking care of pregnant cows). Forty-five percent ( $n$ =95) of the subjects had never worked at another dairy.

Eighty-eight percent $(n=183)$ of the subjects were Hispanic and 12\% $(n=$ 26) were white (of the latter, $81 \%$ were Portuguese). The average worker was 36 years old; the range was from 19 to 69. 
Interviews. Because we were speaking to individuals during work time, we kept the interviews brief so as to minimize the disruption of work operations. We spoke to workers in Spanish and English. Our questions were open-ended. Each subject was asked (1) What is your job in this dairy? (2) How long have you worked in this dairy? (3) Have you ever worked at another dairy? (4) If yes, how long did you work there? and (5) Why did you leave? Questions 4 and 5 were repeated for each of the previous dairy positions the worker had held. The 209 individuals interviewed had worked in 432 distinct dairy jobs.

Responses were given quickly, and we did not probe. We are confident that the answers given were sincere. The process was anonymous; we did not ask for the names of the subjects.

\section{Length of employment}

Using the snapshot approach, the average length of employment at the time of interview was 6.6 years, and the range was from 2 weeks to 40 years. By contrast, when we used the completed-tenure approach, the average length of employment was only 3.5 years. The subset of subjects without previous dairy employment $(n=$ 92), who would not have been interviewed if we had used only the completed-tenure approach, had an average length of employment of 7.1 years, and the range was from 5 weeks to 40 years. The subset of subjects with previous dairy jobs $(n=114)$ had an average length of employment of 6.2 years. On average, these subjects had held three dairy positions, that is, the present job plus two more. As Billikopf noted in 1984, there is great variability

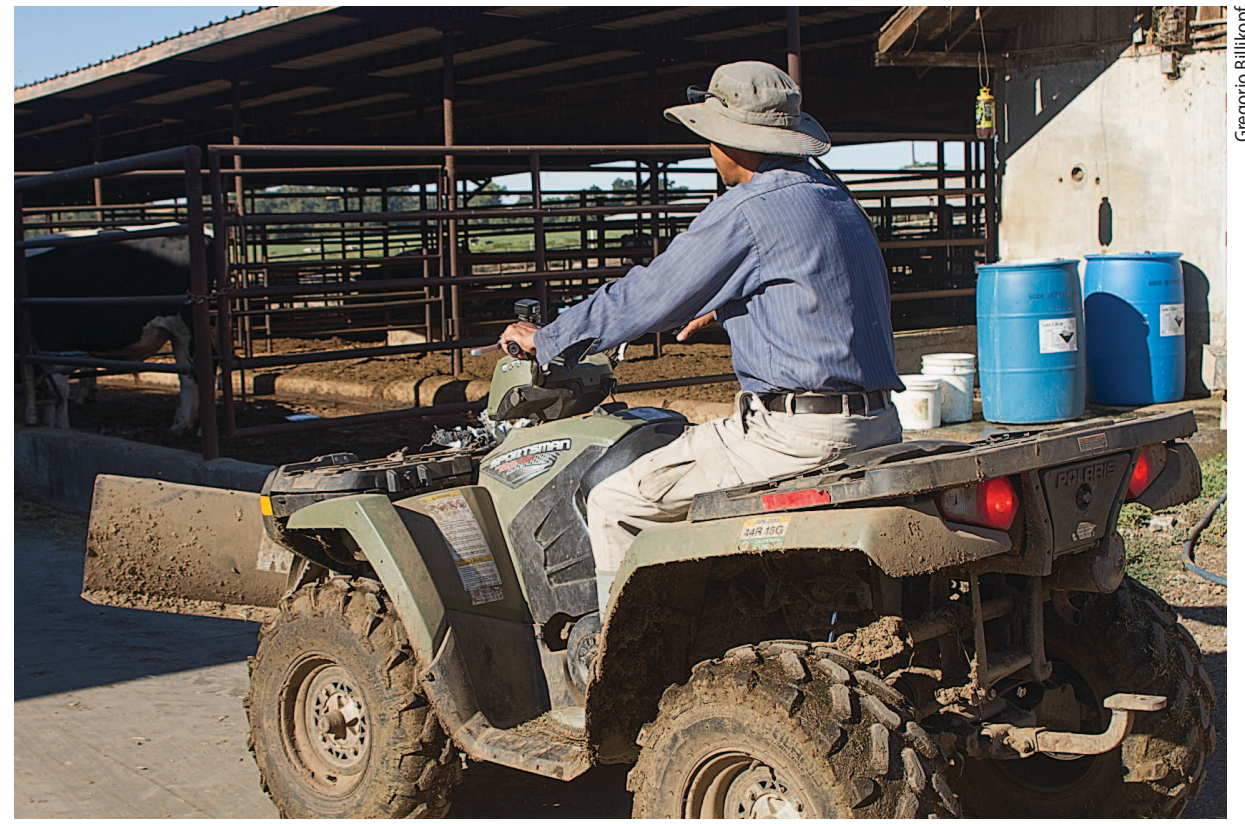

The average length of dairy employment was 6.6 years; the range was from 2 weeks to 40 years. The average number of jobs among people with previous dairy positions was three. in these numbers because some workers seldom change jobs while others do so regularly.

The 1984 data provides further indication that the completed-tenure approach underestimates the true length of employment. Individuals who had never worked in other dairies already had stayed 4 years on the job compared with the average 2.5 years for those who had completed and left dairy positions.

\section{Reasons for leaving}

Most workers had a single prominent reason for leaving their jobs. At times one or two additional reasons affected their decision for leaving. The subjects who had
TABLE 1. Reasons for leaving dairy employment in survey of dairy workers in Merced, San Joaquin and Stanislaus counties, $2009(n=222)$

\begin{tabular}{|c|c|c|c|}
\hline Reason & Primary & Secondary & Tertiary \\
\hline & \multicolumn{3}{|c|}{ 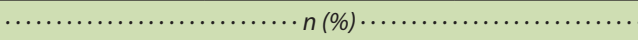 } \\
\hline Compensation and benefits & $65(29)$ & 1 & 0 \\
\hline Dairy economic problems & $32(14)$ & 1 & 0 \\
\hline Personal, family reasons & $24(11)$ & 0 & 0 \\
\hline Working schedules, time off & $24(11)$ & 0 & 1 \\
\hline Housing, transportation & $18(8)$ & 5 & 0 \\
\hline Relations with management & $17(8)$ & 3 & 0 \\
\hline Job duties & $16(7)$ & 3 & 0 \\
\hline Laid off, discharged & $15(7)$ & 0 & 0 \\
\hline Relations with co-workers & $6(3)$ & 0 & 0 \\
\hline Job injuries & $4(2)$ & 0 & 0 \\
\hline Started own dairy & $1(0.5)$ & 0 & 0 \\
\hline
\end{tabular}

left previous dairies $(n=114)$ reported a total of 222 previous dairy positions. For each of these job changes, interviewees gave a main reason for departure. In addition, secondary reasons were given for $8 \%(n=18)$ of the jobs and tertiary reasons were given for $1 \%(n=2)$ (table 1$)$.

The reasons given for leaving previous dairy jobs in the 2009 study, from the most to the least common, included:

Compensation and benefits. Workers typically felt they were either working too many hours for the pay received or that wages were simply too low, regardless of hours worked. Other traditional reasons for worker dissatisfaction in this area were unfulfilled promises often made at the time of employment.

Dairy economic problems. Most typically, the former dairy employer had to sell, or would soon be selling, the farm operation.

Personal and family reasons. This included employees' need to move in order to be closer to family members, and personal or family-related reasons such as divorce or poor health.

Working schedules and time off. This included employees' preferences for a different number of days on or off and the need to take time off to visit family, get married or other personal reasons.

Housing and transportation. This included employee dissatisfaction with their housing and difficulties getting to work. 
Relations with management. Employees reported not getting along with either their direct supervisor or the dairy owner (sometimes one and the same person).

Job duties. Employees reported preferences for certain kinds of work, such as outside work instead of milking, and dissatisfaction with the way their job was designed.

Other reasons cited by workers included being laid off or discharged, poor relations with co-workers, job injuries or leaving to start their own dairy.

\section{Historical comparisons}

It is not clear which measurement approach was used in the 1953 study; later studies used the completed-tenure

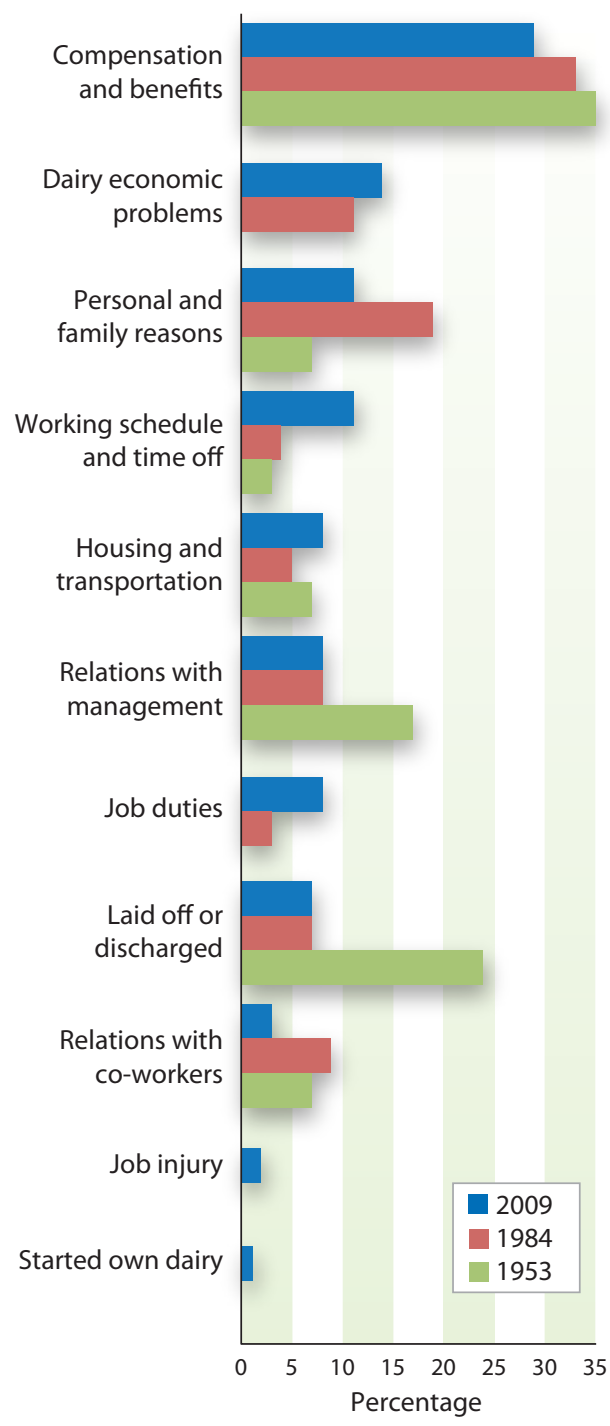

Fig. 1. Reasons for worker turnover in California dairies. $\ln 2009$ survey, $n=209$. approach for comparison purposes. Historical data comparisons showed an upward trend in length of employment (fig. 1). In 1953, average length of employment was about 1 year, in contrast to about 2.5 years in 1984 (a 150\% increase) and 3.5 years in 2009 (an increase of $250 \%$ since 1953 and $40 \%$ since 1984).

Over the years, compensation and benefits are the top reasons employees have given for leaving their jobs. Yet, there seems to be a slight downward trend in the percentage of workers listing it as their reason for leaving: 35\% in 1953, 33\% in 1984 and $29 \%$ in 2009.

Two of the largest changes since 1953 were in layoffs and discharges, which were highly reduced in the more recent surveys (24\% in 1953, 7\% in 1983 and 2009), and dairy economic problems, which increased in the more recent studies (not listed in 1953, 11\% in 1983, $14 \%$ in 2009). We once again note that 2009 was the worst year in the history of the dairy industry. In 1953, economic problems were not listed as a reason for leaving employment, but perhaps this reason was subsumed under layoffs and discharges.

Another key area of change has been in relations with management. In the more recent studies, dairy employees seemed to get along considerably better with their managers or supervisors, with fewer employees listing it as their reason for leaving (17\% in 1953, 8\% in 1983 and 2009). Perhaps this is due to better management practices than in the past as well as employment laws that protect workers from arbitrary treatment.

\section{Related studies}

In a recent survey study conducted in three Eastern dairy states (New York, Pennsylvania and Vermont), snapshot data was collected for length of employment at the time of survey (Stack et al.
2006) (table 2). The authors found that Hispanic employees tended to be younger on average than their non-Hispanic counterparts ( 29 years old versus 36 years old) and have shorter lengths of employment (1.1 compared with 5.8 years). Although Hispanics in California are staying much longer in dairy jobs than their counterparts in the East (5.8 compared with 1.1 years), we found similar differences between Hispanic and non-Hispanic dairy employees in our 2009 data (34 years old versus 48 years old, and lengths of employment of 5.8 compared with 12.4 years). The hiring of Hispanic employees in the Eastern states is a much newer phenomenon than in California.

Also of interest are two studies that measured length of employment around the time of our study in the Canadian pork industry (Marchand et al. 2008) and the New York state dairy industry (Maloney and Grusenmeyer 2005). The New York study confirms the findings of higher turnover among Hispanic employees than non-Hispanic employees in the East; $40 \%$ had worked less than 1 year at the time of the study, and only $1 \%$ had worked 6 years. The Canadian study concerned swine operations rather than dairy, and there was no focus on Hispanic workers. It showed a normal data distribution, with the fewest number of employees having worked for the least amount of time (less than 1 year) or the longest (over 15 years). Unfortunately, for purposes of comparison, both of these studies measured length of employment using ranges rather than exact numbers.

\section{Further questions}

Length of employment among California dairy employees has increased in recent decades, indicating improved stability in the workforce. Despite these gains, however, it seems that much could be done to lengthen Hispanic employees'

TABLE 2. Length of employment in Eastern (2006)* and California dairies (2009)

\begin{tabular}{|c|c|c|c|c|c|c|}
\hline & \multicolumn{3}{|c|}{ Eastern } & \multicolumn{3}{|c|}{ California } \\
\hline & Hispanic & Non-Hispanic & $\begin{array}{c}\text { Probability } t \\
\text { (P) }\end{array}$ & Hispanic & Non-Hispanic & $\begin{array}{c}\text { Probability } † \\
(P)\end{array}$ \\
\hline Age & $29.0(n=192)$ & $35.9(n=770)$ & $<0.01$ & $34.2(n=182)$ & $48.1(n=24)$ & $<0.001$ \\
\hline Tenure (years) & $1.1(n=192)$ & $5.8(n=770)$ & $<0.01$ & $5.8(n=183)$ & $12.4(n=26)$ & $<0.01$ \\
\hline
\end{tabular}


employment in California, considering that non-Hispanic workers have tenures that are twice as long. We wonder how much of the shorter employment tenure for Hispanic employees - who have much in common with Portuguese employees, both being foreign-born and having cultural similarities - has to do with legal status.

Billikopf (2003b) hypothesized that the number of women working in dairies tended to decrease as the number of foreign-born Hispanic employees increased. For instance, he showed that in regions of the United States where there are greater numbers of women working in dairies, there are fewer Hispanics, and vice versa (Billikopf 2003b, 2006, 2009). California seems to be no exception; there is a strong Hispanic presence in the state's dairies and relatively few female employees. Perhaps employers who cannot secure Hispanic employees go out of their way to recruit female employees in order to meet their labor needs.

G. Billikopf is Area Labor Management Farm Advisor, UC Cooperative Extension, Merced, San Joaquin and Stanislaus Counties; and G. González is former Agricultural Student, Modesto Junior College.

\section{References}

Barrett R. 2012. Things Looking Up for Dairy Industry: With Worst Behind Them, Farmers Rebuild, Extend Global Reach. AgWeb/Farm Journal. www.jsonline.com/business/things-looking-up-for-wisconsin-dairy-industrye03ke5i-136492238.html.

Billikopf GE. 1984. Why workers leave dairies. Calif Agr 38(9):26-8.

Billikopf GE. 2003a. Labor Management in Agriculture: Cultivating Personnel Productivity. UC ANR Pub 3417. Oakland, CA. 248 p

Billikopf G. 2003b. USA Wage Survey 2003. www.cnr. berkeley.edu/ucce50/ag-labor/7research/7res05.htm (ac cessed March 23, 2012).

Billikopf G. 2006. USA Wage Survey 2006. www.cnr. berkeley.edu/ucce50/ag-labor/7research/7res06.htm (ac cessed March 23, 2012).

Billikopf G. 2009. USA Wage Survey 2009. www.cnr. berkeley.edu/ucce50/ag-labor/7research/7res08.htm (ac cessed March 23, 2012).

Bliss B. 2010. Cost of Employee Turnover. HireCentrix www.hirecentrix.com/pdf/cost-of-employee-turnover. pdf (accessed March 14, 2012).

Bliss B. 2012. Cost of Employee Turnover. Isquare: The Advisor. www.isquare.com/turnover.cfm (accessed March 14, 2012).

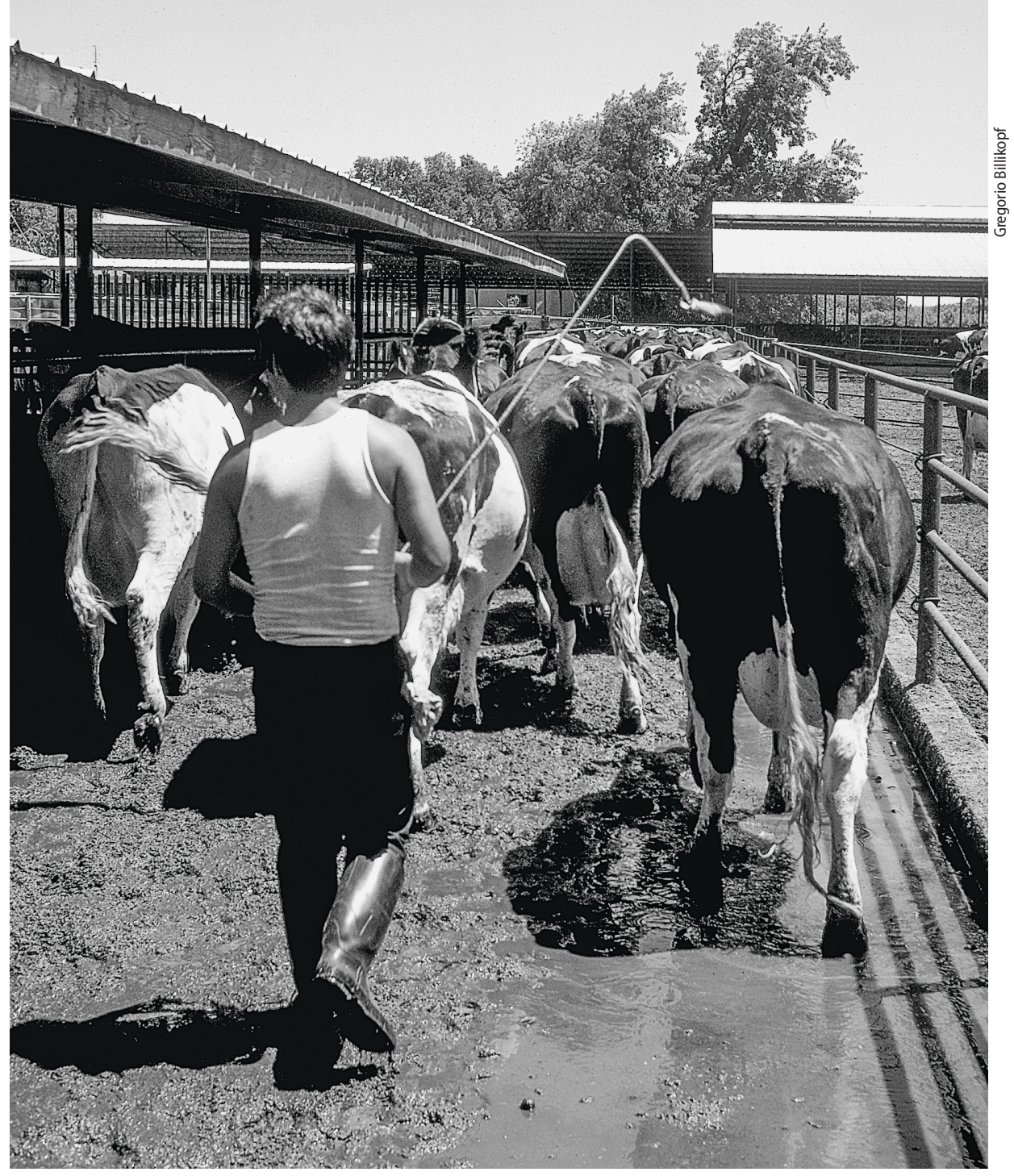

The lead author's previous survey of why workers leave dairies was published in California Agriculture journal in 1984. Lengths of employment have increased $250 \%$ in the Central Valley since an earlier study in 1953 , and $40 \%$ since 1984.

California Milk Advisory Board. 2011. Real California Milk Facts. www.californiadairypressroom.com/Press_Kit/ Dairy_Industry_Facts (accessed July 12, 2011)

[CDFA] California Department of Food and Agriculture. 2011. 2011 First Quarter Cost Comparison. www.cdfa. ca.gov/dairy/uploader/postings/copcostcomp/Default. aspx (accessed July 13, 2011)

CDFA. 2012. California Agricultural Statistics Review 2011 2012. www.cdfa.ca.gov/statistics.

[CEPR] Center of Economic and Policy Research. How Much Does Employee Turnover Really Cost Your Business? www.cepr.net/calculators/turnover_calc.html (accessed March 14, 2012).

Ellerby J. 2010. Challenges and Opportunities for California's Dairy Economy. California Center for Cooperative Development. Davis, CA. p 5.

Fuller V, Viles GL. 1953. A California Labor Study: LaborManagement Relations and Personnel Practices, Market Milk Dairies, Fresno, California. California Agricultural Experiment Station, Giannini Foundation of Agricultural Economics, UC College of Agriculture. Mimeograph Report No 140.

Hill T. 2011. The Economic Recession: Impact on Employment Trends and Retirement Patterns. www.towerswatson.com/united-states/newsletters/insider/5086 (accessed March 21, 2012).

Jex SM, Gudanowski DM. 1992. Efficacy beliefs and work stress: An exploratory study. J Organ Behav 13(5):509-17.
Jordan M. 2009. Got Workers? Dairy Farms Run Low on Labor. Wall Street Journal, July 30. http://online.wsj.com/ article/SB124890678343891639.html\#project\%3DMILK09 07\%26articleTabs\%3Darticle (accessed July 12, 2011). Maloney TR, Grusenmeyer DC. 2005. Survey of Hispanic Dairy Workers in New York State. Dept Applied Econ and Management, College of Agriculture and Life Sciences, Cornell Univ.

Marchand L, Boekhorst J, McEwan K. 2008. Human Resource Needs Assessment for the Pork Industry. Ontario Pork Industry Council and University of Guelph, Ridgetown Campus.

Milkovich GT, Boudreau JW. 1994. Human Resource Management (7th ed.). Boston: Irwin. p 399

O'Connell M, Kung MC. 2007. The cost of employee turnover. Ind Manage 49(1):14-9.

Smith G. 2006. Transform Your Organization from High Turnover to High Retention. www.chartcourse.com/navigator95.html (accessed March 14, 2012).

Stack SG, Jenkins PL, Earle-Richardson G, et al. 2006. Spanish-speaking dairy workers in New York, Pennsylvania and Vermont. J Agromedicine 11(2):37-44. Willis B. 2009. U.S. Recession Worst Since Great Depression, Revised Data Show. www.bloomberg.com/apps/ne ws?pid=newsarchive\&sid=aNivTjr852TI (accessed March 21, 2012). 